\title{
THE VARIATION OF OBLIGATORY PREPOSITION-ARTICLE CONTRACTIONS IN THE INTERLANGUAGE OF ADULT LEARNERS OF PORTUGUESE
}

\section{A variação de contrações obrigatórias entre preposição e artigos na interlíngua de aprendizes adultos de português como língua estrangeira}

Edvan P. BRITO'

\begin{abstract}
This study analyzes the sociolinguistic variation of obligatory contractions between the preposition de and the definite articles in the interlanguage of adult learners of Portuguese as foreign language in the United States. Using this variation phenomenon as an example, the main objective of this pilot study is to discuss the feasibility of using speech data from telecollaborative interactions in interlanguage variation studies. The analyzed data come from four audio-recorded teletandem sessions held in 2017 among nine USbased learners of Portuguese and native speakers of this language in Brazil. The quantitative analysis included three linguistic group factors - preceding word category, gender marking, and number marking- and four social group factors -learner gender, native language, immersion experience, and teletandem session. The results showed that only gender marking was selected as a significant factor for the occurrence of contraction. The study concluded that speech data from telecollaborative interactions can be used as one of the tasks in large scale interlanguage variation studies. However, it also cautions researchers to consider some of the major issues regarding selection of variables, learners' style shifting and stage of acquisition, and technical limitations of this type of interaction.
\end{abstract}

Keywords | Sociolinguistic variation. Interlanguage. Reduced forms. Contractions. Teletandem. Portuguese as a foreign language.
Resumo | Este estudo analisa a variação sociolinguística de contrações obrigatórias entre a preposição de e os artigos definidos na interlíngua de aprendizes adultos de português como língua estrangeira nos Estados Unidos. Usando este fenômeno variável como exemplo, o objetivo principal deste estudo piloto é analisar a viabilidade de usar dados de fala de interações telecolaborativas em estudos de variação de interlíngua. Os dados analisados foram coletados dos áudios gravados de quatro sessões de teletandem que aconteceram, em 2017, entre nove aprendizes de português localizados nos Estados Unidos e falantes nativos desta língua no Brasil. A análise quantitativa incluiu três grupos de fatores linguísticos - classe de palavra precedente, gênero e número- e quatro grupos de fatores sociais - gênero do(a) aprendiz, língua nativa, experiência de imersão e sessão de teletandem. Os resultados indicaram que apenas gênero gramatical foi selecionado como um fator significante para a ocorrência de contração. O estudo concluiu que dados de fala de interações telecolaborativas podem ser usados como uma das técnicas para coleta de dados em estudos de variação de interlíngua de grande porte. Todavia, o estudo também chama a atenção dos pesquisadores para que considerem alguns dos principais problemas relacionados à seleção das variáveis, as mudanças de registro e estágio de aquisição dos aprendizes e as limitações técnicas deste tipo de interação.

Palavras-chave | Variação sociolinguística. Interlíngua. Formas reduzidas. Contrações. Teletandem. Português como língua estrangeira. 
- The variation of obligatory preposition-article contractions in the interlanguage of adult learners of portuguese

\section{Introduction}

This study investigates a linguistic dimension of teletandem, defined as "a collaborative, autonomous and reciprocal method of foreign language learning" that takes place on the Internet (VASSALLO; TELLES, 2006, p. 84). More specifically, it focuses on the use of obligatory contractions between the preposition de (translated into English as 'of' or 'from' and into Spanish as 'de') and the four Portuguese definite articles $o, a$, os, as (translated into English invariably as 'the' and into Spanish as 'el, la, los, las') in the interlanguage of adult learners of Portuguese as a foreign language in the United States and native speakers of Portuguese in Brazil, concentrating on the use of obligatory prepositionarticle contractions by the first group. Given the fact that more and more foreign language programs have encouraged learners' participation in telecollaborative interactions with native speakers or have even incorporated these conversations as an element of the curriculum, this study also aims to discuss the extent to which the data produced in these online interactions are feasible to the analysis of variation in interlanguage, the language developed by a second language learner (SELINKER, 1972).

Variability has been largely accepted as an important aspect of both language (L1) and interlanguage (L2, L3, or additional language). In both cases, many scholars have shown that variation is not random; rather it is systematic, rule-governed, and is influenced by a combination of linguistic and social factors (BAYLEY; TARONE, 2012; LABOV, 1966, 1972a; TARONE, 1988; WEINREICH; LABOV; HERZOG, 1968). Following Young (1991), Regan (2013, p. 4) states that "learners restructure their grammars as they progress through various stages of variability, where they use different forms (target and non-target) towards categorical usage; that is, they use one particular target form finally." The necessity to describe the nature of variability in interlanguage has been a central point in the contributions made by sociolinguistic variation studies to the development of the area of second language acquisition.

In the case of Portuguese as a foreign language, learners' interlanguage presents a considerable amount of variation in their use of reduced forms or contractions involving the prepositions de and definite articles $o, a$, os, $a s$, even though native speakers would realize these combinations categorically as $d o, d a$, dos, and $d a s$, respectively. Knowing when to keep them apart is also part of the implicit knowledge that native speakers have of this grammatical rule. Speaking about the context of the United States, the fact that this contraction rule is not obligatory in either English or Spanish is one of the reasons for L1 English and L1 Spanish learners of Portuguese L3 not to follow it in the target language, especially in early stages of acquisition. 
Another challenge in the acquisition of the preposition-article contraction rule is the notion of grammatical gender in the learners' previous languages. The reality of the United States is such that Portuguese is mostly offered at the college level, when learners have already been introduced to a second language in the preceding stages of their educational career. This second language is usually Spanish for those who have English as their first language and is English for those whose first language is Spanish. In either case, the source of crosslinguistic influence is not always easy to pinpoint, but studies in this area have suggested that $\mathrm{L} 3$ transfer is strongly related to the learner's nonnative language (e.g. DE ANGELIS, 2005a, 2005b; DEWAELE, 1998; HAMMARBERG, 2001; MURPHY, 2003; WILLIAMS; HAMMARBERG, 1998). Nevertheless, as mastering this contraction rule requires a strong understanding of the grammatical gender rules in the Portuguese language, this is particularly difficult for L1 and L2 English speakers given the absence of this feature in this language.

Even though studies of interlanguage variation represent an important field of research within the area of second language acquisition (see BAYLEY; TARONE, 2012; REGAN, 2013), this approach is still understudied among scholars concerned with Portuguese as a foreign language. In fact, the treatment of variation phenomena in PFL textbooks needs to be further developed (CAMPOS, 2017). With this in mind, this study presents a sociolinguistic variation analysis of obligatory preposition-article contractions in the interlanguage of L3 learners of Portuguese, using preliminary data collected from teletandem interactions. In focusing on this variation phenomenon, the study also discusses some of the main issues associated with the nature of linguistic data extracted from computer-mediated-communication environments.

\section{Methods: Vernacular speech in telecollaborative interactions}

Educational institutions represent one of the major sites for learning a second, third or additional language; however, as Bayley and Tarone (2012, p. 51) remind us, "language classrooms naturally elicit formal styles of speech and encourage attention to formal accuracy." The authors also add that those who learn a foreign language in an academic environment often acquire the standard register of that language and sometimes face some difficulties when talking with someone in a context that requires an informal register. These scholars see Internet chat or telecollaborative interactions in general as good resources to complement classroom activities (i.e. role-plays, scenarios, task-based activities) that language instructors usually use in order to trigger informal styles. In their own words, "Internet chat may offer classroom bound learners the opportunity to engage 
- The variation of obligatory preposition-article contractions in the interlanguage of adult learners of portuguese

in authentic interaction with L2 speakers who are not teachers, and expose them to the stylistic differences of L2 that vary according to context" (BAYLEY; TARONE, 2012, p. 51). In this sense, language produced in this kind of environment can be seen as vernacular speech or "the style in which the minimum attention is given to the monitoring of speech" (LABOV, 1972a, p. 208).

Traditionally, sociolinguistic variation studies analyze naturalistic data sets obtained from speakers through the use of sociolinguistic interviews, which include conversation about different topics between the researcher and the participant and other tasks such as reading passage, word lists, and minimal pairs (LABOV, 1972a). By employing each of these tasks and strategically changing the topic of the conversation, the interviewer aims to collect a sample of the interviewee's speech containing a variety of speech styles, ranging from more formal to more casual. According to Labov (1972b, p. 113), another goal of the sociolinguist interview is to minimize the effects of the observer's paradox, the idea that "to obtain the data most important for linguistic theory, we have to observe how people speak when they are not being observed." In the case of second language acquisition studies, the goal of using different methods to obtain data has been to shift the learner's attention from form to meaning. Achieving this goal is even more challenging in the beginning stages of second language acquisition and so the idea of using data from teletandem interactions was seen here as an attempt to solve or minimize this problem.

Another important point in the discussion of the methodology used in sociolinguistic variation research is the notion of speech community, which has been defined as a group of people who have shared characteristics of linguistic use and social practice (PATRICK, 2002; SCHILLING, 2013). After defining the speech community, which may or may not require ethnographic fieldwork, the researcher decides on a plan of how he or she is going to recruit participants for the study in order to have a representative sample of the speech community. To meet this requirement, the researcher often recruits as many speakers as possible to fill cells based on census demographic information (i.e. gender, race, class, age, etc.). With the development of the field of sociolinguistic variation, other sampling techniques for dealing with the representativeness of the speech community have been proposed. One of them is social network, which was used by Milroy (1987) in a sociolinguistic study of Belfast in the 1980s. Using the snowball (also referred to as friend of a friend) technique, the researcher was introduced to new participants as a friend of a friend and so other participants were recruited based on their connections within the existing social network. 
Another way to frame the idea of speech community is to think of it as a community of practice or "an aggregate of people who come together around some enterprise" (ECKERT, 2000, p. 35). The best example of how the idea of community of practice was used in sociolinguistic variation studies was Eckert's (2000) investigation of the linguistic and social practices of the jocks and burnouts of Belten High School, which is located in the suburbs of Detroit. After an extensive period of ethnographic fieldwork, Eckert's sociolinguistic analysis showed that the patterns of variation for each group were consistent with the values, attitudes, and orientations they had about life inside and outside of the school boundaries. The notion of community of practice is useful in the present study because it can be used to identify the participants as a group of people who share the identity of student and are also united by the goal of learning a foreign language, in this case, Portuguese.

As members of a community of practice oriented toward the goal of learning Portuguese, the students engaged in a variety of activities that are usually done by people who attend language classes in an academic setting. These activities included attending class regularly, interacting with instructor and peers, doing homework, taking quizzes, and so on and so forth. Teletandem sessions were added to the course curriculum as speaking activities that would give students an opportunity to practice linguistic structures they were reviewing in class as well as expose them to other elements of the language and the culture in informal conversations with people who were not their instructor. It is also important to mention that, as far as the US-based learners are concerned, their teletandem sessions were categorized as both institutional and integrated, which is when these interactions are not only supported by the academic institution but are also part of the course curriculum, making students' participation mandatory (BRAMMERTS, 2002, p. 86).

Keeping the above discussion in mind, the data analyzed in the present study were collected in 2017 from four audio-recorded teletandem sessions among nine learners of Portuguese as a foreign language in the United States and native speakers of this language located in Brazil. Each session lasted about 50 minutes, which corresponded to the duration of a class period for the US-based learners. During this time, participants normally spent half of the time speaking in Portuguese and the other half speaking in English. Following the three core principles of tandem learning, namely autonomy, reciprocity, and separation of languages (BRAMMERTS, 2003; TELLES, 2015; TELLES; VASSALLO, 2006), the expectation was that participants would enhance their communicative skills overtime by performing these two different roles (foreign language learner and native speaker), developing a sense of agency, and collaborating with one another to achieve their learning goals. 
- The variation of obligatory preposition-article contractions in the interlanguage of adult learners of portuguese

The nine US-based participants, six females and three males, were all enrolled in their first semester of a Portuguese language program. Their ages ranged from 19 to 65 years old and all of them, except for one, were undergraduate students in various stages of their academic career. They were divided into two sub-groups, Group A (GA) and Group B (GB), which corresponded respectively to Portuguese for Spanish Speakers and Elementary Portuguese, the two classes they were taking at the time of the data collection. Group A had five members, of whom three were speakers of Spanish (one was a native-speaker). The remaining two students were the only ones who had had an immersion experience in Brazil. Out of the four members of Group B, only one spoke Spanish. Even though they were in two different classes that followed two different teaching methodologies, all students were assumed to be learning Portuguese as a third or additional language.

The only criterion used to select a participant for the study was the availability of recorded data, which was only technically possible in both the initial and the last teletandem sessions. So, the four teletandem sessions that were selected for analysis correspond to the first and the last teletandem sessions for each of the two groups. In this sense, as Group A had a total of seven sessions over the semester, its interactions were labeled GA1 and GA7. Approximately two months went by between the first and the last interaction. As for Group B, as it had four interactions total, with one and a half months between the first and the last one, its interactions were labeled GB1 and GB4. This group had fewer occurrences of the dependent variable due to the fact that some students interacted in groups of three participants (two Portuguese learners and one native speaker), which limited the number of speaking opportunities for individual students.

After selecting the participants and the interactions, the data were coded separately for the quantitative analysis carried out in the study. The dependent variable was the contraction between preposition de (translated into English as 'of' or 'from' and into Spanish as ' $\mathrm{de}^{\text {') }}$ and the four Portuguese definite articles $o, a$, os, as (translated into English as 'the' and into Spanish as 'el, la, los, las'). Each occurrence of de was coded as "target like" if the learner followed the contraction rule, that is if he or she appropriately contracted the preposition with the definite article in order to produce a target-like combination or reduced form, and as "non-target like" if applying the rule would be inappropriate for the given context. This distinction was also applied to contexts where native speakers usually do not use a definite article, in which cases contraction would not happen. Examples of the coding method are shown below: 
1. Coding examples for contraction between de and definite articles

Target-like: $\quad$ Eu gosto do Brasil. 'I like Brazil.'

Eu gosto de Portugal. 'I like Portugal'

Non-target like: Eu gosto de o Brasil. 'I like Brazil.'

Eu gosto do Portugal. 'I like Portugal'

As it can be seen above, the four different types of occurrences for the dependent variable were combined into two possibilities, namely target-like and non-target like occurrences. The idea here was to account for all the instances where learners applied or did not apply the contraction rule appropriately. In other words, the goal was to see if and when learners were able to identify the contexts in which a contraction was required and contexts where it was not appropriate. It is also important to mention that both learner groups were introduced formally to these contraction rules three weeks prior to their first teletandem interactions.

After classifying each occurrence of de with definite articles based on the specifications made above, this process also included coding for other eight independent variables, of which four were linguistic and four were social. Among the social variables were preceding word category (noun, adjective, and pronoun; adverb and conjunction; or verb), gender marking (masculine or feminine), and number marking (singular or plural). The social variables were learner gender (male or female), native language (Spanish, English, or other), immersion experience (yes or no), and teletandem session (GA1, GA7, GB1, or GB4). More specific information about the collected data and the quantitative analyses carried out for contractions with de are presented in the next session.

\section{Quantitative Results}

The data collection yielded a total of 104 tokens of contractions with de, of which 80 were target like, meaning that the rule for making a contraction or for not making one was followed by the learner, and 24 were non-target like (Please see the previous session for more information). The influence of the seven independent variables (preceding word category, gender marking, number marking, learner gender, native language, immersion experience, and teletandem session) for the dependent variable was measured using the binomial one level analysis in Rbrul (JOHNSON, 2009), a variable rule program that runs within the $\mathrm{R}$ programming language environment. For this procedure, the non-target 
- The variation of obligatory preposition-article contractions in the interlanguage of adult learners of portuguese

like occurrences of contraction were treated as the application value. Table 1 shows the quantitative results for contractions with $d e$.

Table 1. Multivariate analysis of the contribution of linguistic and social factors to the probability of non-target de contractions

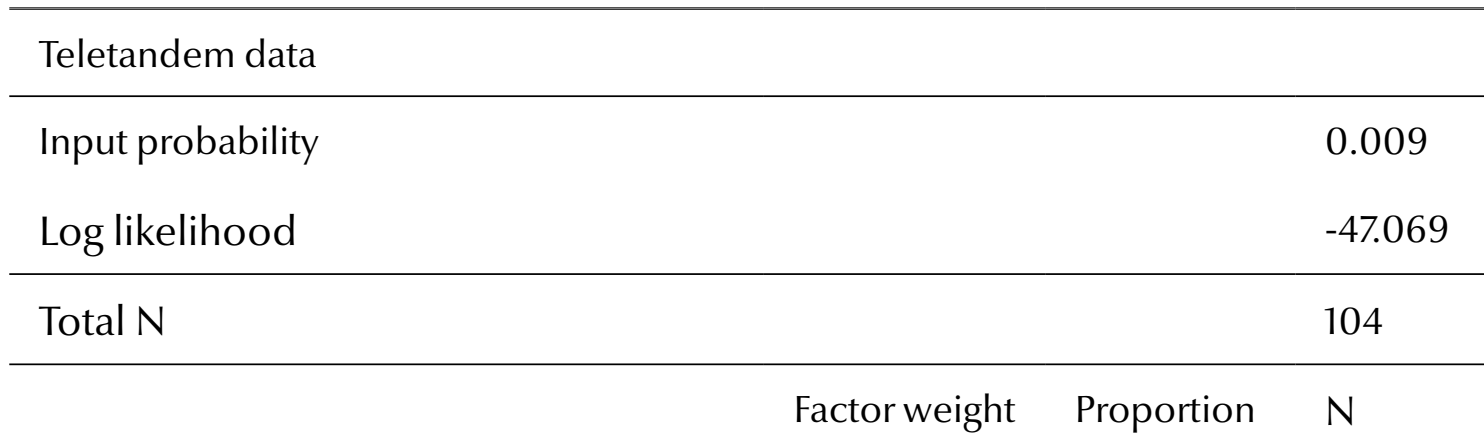

Gender marking $(p>0.01)$

Feminine

$0.69 \quad 31$

Masculine

0.30

19

72

Number marking (Not significant)

$\begin{array}{llll}\text { Plural } & 0.62 & 33 & 18\end{array}$

$\begin{array}{llll}\text { Singular } & 0.37 & 20 & 86\end{array}$

Preceding word category (Not

significant)

$\begin{array}{llcc}\text { Noun, Adjective and Pronoun } & 0.52 & 25 & 59 \\ \text { Adverb and Conjunction } & 0.48 & 28 & 14 \\ \text { Verb } & 0.48 & 16 & 31\end{array}$

Learner gender (Not significant)
Male
0.65
25
43
Female
0.34
21
61 
Native language (Not significant)

\begin{tabular}{llll} 
Spanish & 0.87 & 50 & 4 \\
English & 0.45 & 23 & 90 \\
Other languages & 0.14 & 10 & 10 \\
& & & \\
Immersion experience (Not significant) & & 19 & 46 \\
Yes & 0.50 & 25 & 58 \\
No & 0.49 & & \\
& & & 39 \\
Teletandem session (Not significant) & & 35 & 20 \\
Group A, session 7 & 0.99 & 25 & 38 \\
Group B, session 1 & 0.98 & 13 & 7 \\
Group A, session 1 & 0.98 & 00 & \\
Group B, session 4 & 0.00 & & \\
\hline
\end{tabular}

\section{Linguistic factors}

The quantitative analysis included three linguistic or internal factors, namely preceding word category, gender marking, number marking. The results that appear in Table 1 show that gender marking was the only linguistic factor that significantly influenced the occurrence of non-target de contractions. Based on these results, feminine definite articles favored non-target like contractions of $d e$, with a probability weight of 0.69 . Conversely, masculine define articles disfavored this kind of contraction, with a factor weight of 0.30 .

Even though they were not selected as significant by Rbrul, the other two linguistic factors - number marking and preceding word category - also showed interesting results. For number marking, the quantitative results showed that definite articles marked for plural favored the non-application of the contraction rule. The probability weight for this factor 
- The variation of obligatory preposition-article contractions in the interlanguage of adult learners of portuguese

was 0.62. Unmarked definite article, on the other hand, disfavored this feature. This means that the grammatical rules for de contractions had more chances to be followed by learners when the definite article, and consequently the noun phrase, was in the singular form. In the case of preceding word category, the results showed that the factors considered for these factor group had an almost neutral effect on non-target like de contractions, having factor weights of 0.52 for nouns, adjectives and pronouns and 0.48 for both adverbs and conjunctions and verbs.

\section{Social factors}

The results for the social or external factors included in the quantitative analysis, namely learner gender, native language, immersion experience, and teletandem session, also point to important information about the use of contractions in the interlanguage of learners of Portuguese as a foreign language, even though none of them was selected as significant for the occurrence of non-target like de contractions.

In the case of learner gender, the quantitative results showed that male learners favored the non-target like de contractions while female learners disfavored it. The probability weight was of 0.65 for the first group and of 0.34 for the second one. As far as native language is concerned, the results indicated that the non-target like use of de contraction was favored by Spanish native speakers (factor weight of 0.87). It is important to mention that there was only one participant that met this criterion and this particular speaker produced 4 contractions with de, of which 2 (50\%) were non-target like. This linguistic feature was slightly disfavored by English native speakers (factor weight of 0.45 ) and strongly disfavored by the native speakers of other languages (factor weight of 0.14).

Another social factor included in the quantitative analysis was immersion experience, which showed no effect on the dependent variable. Nevertheless, it is worth noting that only two learners had previously spent some time in a Portuguese-speaking country. Even though they produced almost half of all de contraction cases with a total of 46, the proportion of contractions errors they had was of 19 percent, compared to 25 percent of the rest of the group. Even though these two speakers had developed a certain level of fluency when speaking in Portuguese due to the fact that they probably focused more on meaning than on form than the other learners, their use of the contraction rule shows that they were still processing the acquisition of this linguistic feature. 
The last social factor that was included in the quantitative analysis was teletandem session or the initial and final sessions for each of the two groups of learners considered in the study (Group A - GA and Group B - GB). The results for this factor were compromised not only by the small number of occurrences produced by group $B$ ( 7 occurrences) but also the inexistence of non-target like de contractions for this group in their second interaction. Even though the small number of occurrences can be blamed to the fact that this interaction did not have a large amount of speech data compared to the other ones, it is difficult to determine if their use of the contraction rule would remain the same if the learners had actually spoken more. In what follows, I comment on the main points regarding the results presented in this session and on the major challenges faced during the development of this research project.

\section{Discussion}

Looking at the quantitative results presented in the previous sessions, it is possible to see some interesting points regarding the effect of some of the group factors included in the analysis on the use of non-target like de contractions by the group of learners of Portuguese as a foreign language. Even though the amount of data used in the quantitative analysis jeopardizes any attempt to generalize these results, it is worth noting the effect of gender marking, the only group factor selected as significant. As seen above, nontarget like de contractions were favored when the article, and consequently the whole noun phrase, was marked for gender or in the feminine form. This is actually expected, given the fact that grammatical gender is a difficult morphological feature to acquire by L3 learners of Portuguese, especially if their L1 or L2 is English (BRITO, 2015; DEKEYSER, 2005). In this case, appropriate use of the contraction rule requires mastering of the grammatical gender first and so it will be interesting to test the development of these two variables in a longitudinal study.

As it was discussed earlier, collected data from telecollaborative interactions, such as those from teletandem, can be a good solution to the challenge of recording vernacular speech for a sociolinguistic variation analysis of interlanguage. However, a few things should be taken into consideration by researchers attempting to do accomplish this goal. For example, the researcher could use these data as an additional task to be performed by learner, which could be compared to recordings of sociolinguistic interviews, including its usual parts such as spontaneous conversation, narrative, minimal pair, word list, and reading passage. The ultimate goal is to be able to get a range of speech styles, ranging from more formal (careful) to less formal (casual) (LABOV, 1972c) and so, as discussed 
- The variation of obligatory preposition-article contractions in the interlanguage of adult learners of portuguese

above, telecollaborative interactions can provide learners with great opportunities to produce vernacular speech.

The design of a sociolinguistic variation study of interlanguage should also consider the issue of variable selection, especially if the researcher is considering using data from telecollaborative interactions. For example, it is necessary to think about the frequency of the linguistic variable. In early stages of acquisition, it is probably a good idea to analyze a phonological item whose occurrence will not be an issue even if the learner does not or is not able to produce a large amount of speech data. As Wolfram (1993, p. 205-206) advises us, "Items that are rare, either because of the relative infrequency of the structure in ordinary conversation or because of conscious suppression in an interview situation are not good candidates for variation analysis." In the case of this study, even though preposition-article contractions are fairly frequent linguistic features in the speech of even beginning learners, some of the participants did not produce as much data as it had been expected. This, as a result, compromises not only the analysis itself but also any possible generalization based on it.

The technical characteristics of the medium may also pose some challenges. One of them has to do with the instability of the Internet connection itself, which can jeopardize the quality of the data, especially if the researcher intends to analyze a suprasegmental feature of the speech, such as stress, tone, pitch, length of sounds, and word juncture. Moreover, fluctuations in the sound quality may compromise the researcher's ability to examine the formative elements of vowels and consonants, for example. A way to get around this challenge is to make sure that minimum requirements for audio recording are met in both ends of the interaction. It is also important to keep in mind that people will respond differently to the idea that their conversation will be mediated by a computer screen. In other words, talking with someone through a computer screen may be totally ordinary for some people but it may also be terrifying or intimidating for others, especially in a foreign language.

\section{Final considerations}

The present study investigated the sociolinguistic variation of contractions between the preposition de and the definite articles $o, a, o s$, and $a s$ in the interlanguage of nine learners of Portuguese as foreign language from an American university. The analyzed data were collected from audio-recorded teletandem sessions among the Portuguese learners and native speakers of this language in Brazil. Out of the seven independent variables or group factors included in the quantitative analysis (preceding word category, gender 
marking, number marking, learner gender, native language, immersion experience, and teletandem session), only gender marking was selected as significant. Within this group factor, feminine definite articles or noun phrases favored the occurrence of non-target like de contractions while masculine ones, disfavored it. Stated differently, articles in the feminine form influenced negatively the application of the contraction rule between the preposition de and the article. This was expected given the fact that articles in English, the native language of most of the participants, are not marked for gender, and so learners may have found it easier to apply the contraction rule in contexts with fewer elements to attend to. More research is needed to first determine the source of crosslinguistic influence in this case and then the specific patterns of use of contraction rules in the interlanguage.

Based on the experience gained with the realization of the project, it is possible to say that data gathered from telecollaborative interactions can be used as an additional task in the sociolinguistic variation analysis of interlanguage. As the data produced in such interactions tend to be more informal, they can be analyzed as a sample of the learners' vernacular speech, which may be difficult to get in academic settings. It is also important to consider some of the issues that may pose a problem during and after the data collection, including variable selection, what linguistic features learners will be producing more consistently and when, and technical limitations imposed by the nature of computer mediated communications themselves.

\section{References}

BAYLEY, R.; TARONE, E. Variationist perspectives. In: GASS, S. M.; MACKEY, A. (ed.). The Routledge handbook of second language acquisition. New York: Routledge, 2012. p. 41-56.

BRAMMERTS, H. Aprendizagem autónoma de línguas em tandem: desenvolvimento de um conceito. In: DELILLE, K. H.; CHICHORRO, A. (ed.). Aprendizagem autónoma de línguas em tandem. Lisboa: Edições Colibri, 2002. p. 15-25.

BRAMMERTS, H. Autonomous language learning in tandem: The development of a concept. In: LEWIS, T.; WALKER, L. (ed.). Autonomous language learning in tandem. Sheffield: Academy Electronic Publications Limited, 2003. p. 27-36.

BRITO, E. P. Grammatical gender in the interlanguage of English-speaking learners of Portuguese. Portuguese Language Journal, v. 9, Article 7, 2015. 
- The variation of obligatory preposition-article contractions in the interlanguage of adult learners of portuguese

CAMPOS, F. R. A variação linguística no livro didático de PLE e sua percepção pelo professor. Revista Sociodialeto, v. 7, p. 20-51, 2017. Available in: http://sociodialeto.ojs. galoa.com.br/index.php/sociodialeto/article/view/54. Access: 1 nov. 2018.

DE ANGELIS, G. Interlanguage transfer of function words. Language Learning, v. 55, p. 379-414, 2005a.

DE ANGELIS, G. Multilingualism and non-native lexical transfer: An identification problem. International Journal of Multilingualism, v. 2, p. 1-25, 2005b.

DEKEYSER, R. M. What makes learning second language grammar difficult? A review of issues. Language Learning, v. 55, p. 1-25, 2005.

DEWAELE, J. M. Lexical inventions: French interlanguage as L2 versus L3. Applied Linguistics, v. 19, p. 471-490, 1998.

ECKERT, P. Linguistic variation as social practice. Malden, MA: Blackwell, 2000.

HAMMARBERG, B. Roles of L1 and L2 in L3 production and acquisition. In: CENOZ, J.; HUFEISEN, B. JESSNER, U. (ed.). Cross-linguistic influence in third language acquisition: Psycholinguistic perspectives. Clevedon: Multilingual Matters, 2001. p. 21-41.

JOHNSON, D. E. Getting off the GoldVarb standard: Introducing Rbrul for mixed-effects variable rule analysis. Linguistics and Language Compass, v. 3, p. 359-383, 2009.

LABOV, W. The social stratification of English in New York City. Washington: Center for Applied Linguistics, 1966.

LABOV, W. Sociolinguistic patterns. Philadelphia: University of Philadelphia Press, 1972a.

LABOV, W. Some principles of linguistic methodology. Language in Society, v. 1, p. 97$120,1972 b$.

LABOV, W. The isolation of contextual styles. In: Sociolinguistic patterns. Philadelphia: University of Pennsylvania Press, 1972c. p. 70-109.

MILROY, L. Language and social networks. 2. ed. Oxford: Basil Blackwell, 1987. 
MURPHY, S. Second language transfer during third language acquisition. Columbia University Working Papers in TESOL and Applied Linguistics, v. 3, p. 1-21, 2003.

PATRICK, P. L. The speech community. In: CHAMBERS, J. K.; TRUDGILL, P.; SCHILLING, N. (eds.). The handbook of language variation and change. Malden, MA: Blackwell, 2002. p. 573-597.

REGAN, V. Variation. In: HERSCHENSOHN, J.; YOUNG-SCHOLTEN, M. (ed.). Cambridge handbooks in language and linguistics: The Cambridge handbook of second language acquisition. Cambridge: Cambridge University Press, 2013. Available in: http://0-search.credoreference.com.library.uark.edu/content/entry/cuphseclaq/ variation/0?institutionld=5281. Access: 3 out. 2017.

SCHILLING, N. Sociolinguistic fieldwork. Cambridge: Cambridge University Press, 2013.

SELINKER, L. Interlanguage. International Review of Applied Linguistics, v. 10, p. 209$241,1972$.

TARONE, E. Variation in interlanguage. London: Edward Arnold, 1988.

TELLES, J. A. Learning foreign languages in teletandem: Resources and strategies. D.E.L.T.A., v. 31, p. 603-632, 2015.

TELLES, J. A.; VASSALLO, M. L. Foreign language learning in-tandem: Teletandem as an alternative proposal in CALLT. The ESPecialist, v. 27, p. 189-212, 2006. Available in: http:// citeseerx.ist.psu.edu/viewdoc/download?doi=10.1.1.1025.2815\&rep=rep1\&type=pdf. Access: 18 dez. 2018.

VASSALLO, M. L.; TELLES, J. A. Foreign language learning in-tandem: Theoretical principles and research perspectives. The ESPecialist, v, 27, p. 83-118, 2006. Available in: http:// citeseerx.ist.psu.edu/viewdoc/download?doi=10.1.1.845.2443\&rep=rep1\&type=pdf. Access: 1 nov. 2018.

WEINREICH, U.; LABOV, W.; HERZOG, M. Empirical foundations for a theory of language change. In: LEHMANN, W. P.; MALKIEL, Y. (ed.). Directions for historical linguistics. Austin, TX: University of Texas Press, 1968. p. 95-188.

WILLIAMS, S.; HAMMARBERG, B. Language switches in L3 production: Implications for a polyglot speaking model. Applied Linguistics, v. 19, p. 295-333, 1998. 
- The variation of obligatory preposition-article contractions in the interlanguage of adult learners of portuguese

WOLFRAM, W. Identifying and interpreting variables. In: PRESTON, D. R. (ed.). American Dialect Research. Amsterdam and Philadelphia: John Benjamins, 1993. p. 193-221.

YOUNG, R. Variation in interlanguage morphology. New York: Peter Lang, 1991.

COMO CITAR ESTE ARTIGO: BRITO, Edvan P. The variation of obligatory prepositionarticle contractions in the interlanguage of adult learners of Portuguese. Revista do GEL, v. 15, n. 3, p. 241-256, 2018. Disponível em: https://revistadogel.gel.org.br/

DOI: http://dx.doi.org/10.21165/gel.v15i3.2390

Submetido em: 01/11/2018 | Aceito em: 21/12/2018. 